\title{
Affinity selection of FGF2-binding heparan sulfates for ex vivo expansion of human mesenchymal stem cells ${ }^{\dagger}$
}

Sampath Jeewantha Wijesinghe ${ }^{1 \#}$, Ling Ling ${ }^{1 \#}$, Sadasivam Murali ${ }^{1}$, Yeong Hui Qing ${ }^{1}$, Simon F.R. Hinkley ${ }^{2}$, Susan M. Carnachan ${ }^{2}$, Tracey J. Bell ${ }^{2}$, Kunchithapadam Swaminathan ${ }^{3}$, James H. Hui ${ }^{4,}$ Andre J. van Wijnen ${ }^{5}$, Victor Nurcombe ${ }^{1}$, Simon M. Cool ${ }^{1,4^{*}}$

${ }^{1}$ Institute of Medical Biology, Agency for Science Technology and Research (A*STAR), Singapore 138648.

${ }^{2}$ The Ferrier Research Institute, Victoria University of Wellington, Lower Hutt 5040, New Zealand.

${ }^{3}$ Department of Biological Sciences, National University of Singapore, Singapore 117543

${ }^{4}$ Department of Orthopaedic Surgery, Yong Loo Lin School of Medicine, National University of Singapore, Singapore 119074.

${ }^{5}$ Department of Orthopedic Surgery \& Biochemistry and Molecular Biology, Mayo Clinic, Rochester, MN 55905, USA.

\# These authors contributed equally

*Corresponding author:

Simon Cool, $\mathrm{PhD}$

Institute of Medical Biology

8A Biomedical Grove, \#06-06 Immunos, Singapore 138648

Tel $+65-64070176$

\footnotetext{
+ This article has been accepted for publication and undergone full peer review but has not been through the copyediting, typesetting, pagination and proofreading process, which may lead to differences between this version and the Version of Record. Please cite this article as doi: [10.1002/jcp.25454]
}

Additional Supporting Information may be found in the online version of this article. 
Fax: $+65-64789477$

Email: simon.cool@imb.a-star.edu.sg

Authors declare no conflict of interest.

Running title: Heparan sulfate as a stem cell culture adjuvant 
Abstract

The future of human mesenchymal stem cells (hMSCs) as a successful cell therapy relies on bioprocessing strategies to improve the scalability of these cells without compromising their therapeutic ability. The culture-expansion of hMSCs can be enhanced by supplementation with growth factors, particularly fibroblast growth factor 2 (FGF2). The biological activity of FGF2 is controlled through interactions with heparan sulfate (HS) that facilitates ligand-receptor complex formation. We previously reported on an FGF2interacting HS variant (termed HS2) isolated in microgram amounts from embryonic tissue by anionic exchange chromatography that increased the proliferation and potency of hMSCs. Here we detail the isolation of gram amounts of an FGF2 affinity-purified HS variant (HS8) using a scalable platform technology previously employed to generate HS variants with increased affinity for BMP-2 or $\mathrm{VEGF}_{165}$. This process used a peptide sequence derived from the heparin-binding domain of FGF2 as a substrate to affinity-isolate HS8 from a commercially available source of porcine mucosal HS. Our data show that HS8 binds to FGF2 with higher affinity than to FGF1, FGF7, BMP2, PDGF-BB, or VEGF 165 . Also, HS8 protects FGF2 from thermal destabilization and increases FGF signaling and hMSC proliferation through FGF receptor 1. Long-term supplementation of cultures with HS8 increased both hMSC numbers and their colony-forming efficiency without adversely affecting the expression of hMSC-related surface antigens. This strategy further exemplifies the utility of affinity-purifying HS variants against particular ligands important to the stem cell microenvironment and advocates for their addition as adjuvants for the culture-expansion of hMSCs destined for cellular therapy. 
Key words:

\section{- fibroblast growth factor}

- glycosaminoglycans

- bone marrow stromal cells

- culture supplements

\section{Introduction}

The multipotent human mesenchymal stem cells (hMSCs), resident in bone marrow niche, play key roles in maintaining and replenishing tissues. Their recently discovered bioactive roles as cellular modulators, and inherent trophic activities have gained hMSCs the reputation of "injury drugstores" (Caplan and Correa, 2011). Many clinical interventions are considering the therapeutic potential of MSCs, including wound healing (Chen et al., 2008; Maxson et al., 2012; Shin and Peterson, 2013; Wu et al., 2014) and skeletal tissue regeneration (Bueno and Glowacki, 2009; Chatterjea et al., 2010; Undale et al., 2009), as well as treatment for graft-versus-host disease (Le Blanc et al., 2008; Meuleman et al., 2009; Ren et al., 2009; Shi et al., 2010; Toubai et al., 2009), kidney injuries (Morigi et al., 2004) and myocardial infarctions (Shabbir et al., 2009). The growing issue of aging populations worldwide also demands better therapies for degenerative diseases. The potential for hMSCs to restore tissue function and thereby treat the root cause of degenerative disease may substantially contribute to address this growing need (Syed and Evans, 2013).

The wider application of hMSC therapies is limited by an insufficiency in the numbers of cells required to meet the growing clinical need, as native hMSCs in situ only account for a small fraction $(0.01-0.0001 \%)$ of the bone marrow mononuclear cell population (BMMNC) (Caplan, 2009). To address the inherent limitation of cell number, many studies investigate the scale-up of hMSCs in ex vivo settings by attempting to mimic 
essential components within the bone marrow microenvironment. A number of these studies use reconstituted extracellular matrix (ECM) as a substrate for cell expansion or exogenous growth factors as culture supplements.

Fibroblast growth factor 2 (FGF2) is a widely used culture supplement that increases the proliferation of hMSCs (Auletta et al., 2011; Dombrowski et al., 2009; Gharibi and Hughes, 2012; Ling et al., 2006; Ng et al., 2008; Sotiropoulou et al., 2006). Such supplementation increases the chondrogenic potential of hMSCs (Hagmann et al., 2013; Tsutsumi et al., 2001) and maintains both their osteogenic development and immunosuppressive ability (Auletta et al., 2011; Gharibi and Hughes, 2012; Sotiropoulou et al., 2006). Autocrine FGF2 may enhance the multipotentiality of human adipose-derived MSCs (Rider et al., 2008), although FGF2 supplementation during the isolation of either hMSCs or rMSCs from bone marrow may significantly reduce their colony-forming efficiency (Frescaline et al., 2012; Martin et al., 1997). MSC cultures expanded in the presence of FGF2 may contain more differentiated progenitors and cells with reduced expression of CD49, STRO-1, CD90 and CD105 (Gharibi and Hughes, 2012; Gronthos et al., 1999; Hagmann et al., 2013; Walsh et al., 2000). While FGF2 is an important growth factor for stem cells, long-term supplementation of exogenous FGF2 can adversely affect their stemness. Indeed, FGF2 is a potent mitogen for rat MSCs, however these cells fail to undergo osteogenic differentiation in the presence of FGF2 (Dombrowski et al., 2009). Moreover, FGF2 is both expensive and short-acting in culture. Rather than exogenous supplementation with FGF2, we reasoned that because FGF2 is already produced by cultured hMSCs, the additional of an FGF2-binding HS could provide a suitable microenvironment whereby endogenous FGF2 signaling was enhanced.

HS glycosaminoglycans are key extracellular components for normal embryogenesis and regulate the growth factors required for self-renewal and lineage-specification of both 
embryonic and adult stem cells. Heparan sulfate proteoglycans (HSPGs) are expressed in almost all animal tissues (Gandhi and Mancera, 2008; Ori et al., 2008). Their linear HS chains are made of repeating disaccharide units (Ori et al., 2009) of uronic acid and Dglucosamine (Gandhi and Mancera, 2008). Different forms of HS bind and regulate a broad array of developmental factors, including members of the FGF family (Pellegrini, 2001). Particular forms of HS associate directly with FGFs and their cognate receptors (FGFR1-4) to form a trimeric complex, a pre-requisite for the activation of FGF signaling and subsequent proliferation, differentiation, migration and survival (Nugent and Edelman, 1992).

Previous work from our laboratory has shown that distinct HS fractions with increased binding for particular ligands can be isolated by conventional chromatography. For example, one HS variant from murine embryos is capable of accelerating the proliferation of both rat and human MSCs without compromising their multipotentiality (Dombrowski et al., 2009; Helledie et al., 2012; Nurcombe et al., 2000). Human MSCs culture-expanded in the presence of this embryonic HS variant show enhance bone forming ability when transplanted into a rat femoral defect (Helledie et al., 2012). Other HS variants extracted from mouse liver, a highly regenerative organ, can also increase hMSC expansion and osteogenic differentiation (Murali et al., 2011). Although these studies highlight the utility of using HS variants as culture supplements, such sources of raw material are not able to meet future demands for large-scale production of MSCs destined for clinical use.

In order to scale the production of an HS variant capable of binding and activating FGF2, we adapted our approach previously used to scale both a BMP-2 and a VEGF $165^{-}$ binding HS (Murali et al., 2013; Wang et al., 2014). However, for the affinity trap we used a peptide corresponding to the heparin-binding domain of FGF2 (Cardin and Weintraub, 1989). We show that this scaled HS variant (HS8) has a distinct biochemical composition and is able to enhance hMSC proliferation without adversely affecting their therapeutic potency. 


\section{Materials and Methods}

\section{Peptide synthesis}

FGF2-HBD peptides, as previously described (Ashikari-Hada et al., 2004; Baird et al., 1988; Cardin and Weintraub, 1989; Gandhi and Mancera, 2008; Kinsella et al., 1998; Lee et al., 2007; Ori et al., 2009) were synthesized by GL Biochem (Shanghai) Ltd and the Nanyang Technological University, Singapore-SBS Peptide Core Facility. The peptides were biotinylated and an aminohexanoic acid (Ahx) linker was inserted between the biotin and the peptide to ensure free movement when the peptide was applied to the streptavidin column prior to affinity fractionation of heparan sulfate.

\section{[3H]-heparin binding assay}

Analysis of $\left[{ }^{3} \mathrm{H}\right]$-heparin binding was performed as described previously (Baird et al., 1988). Briefly, biotinylated FGF2-HBD peptides dissolved in PBS were spotted onto $0.2 \mu \mathrm{M}$ nitrocellulose membranes (Biorad) and incubated with $0.1 \mu \mathrm{Ci}$ of ${ }^{3} \mathrm{H}$-heparin (Perkin Elmer) in $4 \%$ BSA (Sigma-Aldrich) at room temperature overnight with moderate agitation. The unbound heparin was removed by rinsing with PBS, and the membrane immersed in Ultima Gold scintillation cocktail (Perkin Elmer). Bound ${ }^{3} \mathrm{H}$-heparin was measured by liquid scintillation counting using a Tri-carb 2800TR counter (Perkin Elmer).

\section{Gylcosaminoglycan-Protein affinity by ELISA}

A modified ELISA was used to determine the affinity between protein and HS, as described previously (Bramono et al., 2012; Murali et al., 2011). GAG-binding plates (Iduron) coated with heparin (Sigma Aldrich) or HS (Celsus laboratories) were incubated with the indicated amounts of biotinylated peptides or growth factors (R\&D Systems) in blocking buffer. After washing, the peptides or proteins bound to the heparin/HS-coated 
plates were incubated with ExtrAvidin (Sigma Aldrich) or biotinylated antibodies against the proteins before being exposed to ExtrAvidin. Bound proteins were detected using the development reagent SIGMAFAST ${ }^{\mathrm{TM}}$ Nitrophenyl phosphate (Sigma Aldrich) and quantified by measuring absorbance at $405 \mathrm{~nm}$.

\section{Isolation of FGF2-binding HS}

HS variants with high affinity for FGF2 were isolated by affinity chromatography as previously described for BMP2 and $\mathrm{VEGF}_{165}$ (Murali et al., 2013; Wang et al., 2014). Briefly, biotinylated FGF2-HBD peptide was coupled to HiTrap streptavidin HP columns (GE Healthcare) to fractionate crude porcine mucosal HS ( $\left.\mathrm{HS}^{\mathrm{pm}}\right)$ (Celsus, Lot HO-10697). The FGF2-binding HS fractions were then eluted with $1.5 \mathrm{M} \mathrm{NaCl}$. The isolated $\mathrm{HS}$ was then desalted and freeze-dried.

Capillary electrophoresis - disaccharide analysis

Capillary electrophoresis (CE) was performed against known disaccharide standards (Iduron) to compare the disaccharide profiles of affinity-isolated HS with that of the original $\mathrm{HS}^{\mathrm{pm}}$ material. HS $(1 \mathrm{mg})$ in sodium acetate buffer $(100 \mathrm{mM}$ containing $10 \mathrm{mM}$ calcium acetate, $\mathrm{pH} 7.0,500 \mathrm{ml}$ ) was digested with $2.5 \mathrm{mIU}$ of heparitinase (Seikagaku Corporation) at $37^{\circ} \mathrm{C}$ for $72 \mathrm{~h}$ with an additional dose after $24 \mathrm{~h}$. The digestion was terminated by heating to $100{ }^{\circ} \mathrm{C}$ for $5 \mathrm{~min}$. The $\mathrm{CE}$ analysis was performed using an Agilent3DCE instrument (Agilent Technologies). The disaccharides were identified by their migration times relative to the internal standard ( $\triangle \mathrm{UA}, 2 \mathrm{~S}-\mathrm{GlcNCOEt}, 6 \mathrm{~S})$ and quantified according to the calibration curves generated using the disaccharide standards.

\section{Heparin-agarose bead competition assays}


To determine the competitive affinity of HS for FGF2, a heparin-bead suspension was prepared by mixing heparin-agarose beads (Sigma Aldrich) with an equal volume of Biogel P-30 (BioRad). The HS fraction was then pre-coupled with FGF2 (100 $\mu \mathrm{l})$ before being incubated with $40 \mu 1$ heparin-bead suspension for $30 \mathrm{~min}$. The complex was then washed (1 $\mathrm{ml}$ of $1 \%$ BSA in PBS and $1 \mathrm{ml}$ of $0.02 \%$ Tween20 in PBS) and then incubated with $100 \mu \mathrm{l}$ of biotinylated anti-FGF2 (R\&D Systems) for $1 \mathrm{~h}$. Next, TMB substrate (100 $\mu \mathrm{l})$ (R\&D Systems) was added for $30 \mathrm{~min}$ and the reaction stopped with $2 \mathrm{M} \mathrm{H}_{2} \mathrm{SO}_{4}(50 \mu \mathrm{l})$. The absorbance of the color reaction resulting from TMB conversion was read at $450 \mathrm{~nm}$, and the data were normalized against blank beads. The beads were washed and then boiled at $95^{\circ} \mathrm{C}$ for $5 \mathrm{~min}$ in $2 \mathrm{X}$ Laemmli buffer (Sigma Aldrich) to denature the protein. The beads were separated by micro-centrifugation from the supernatant, which was then analyzed by Western blotting.

Anti-coagulation assay

The anti-coagulative capacity of the HS variants was determined by their effect on antithrombin III activity with the COATEST Heparin Kit (Chromogenix) following the manufacturer's recommendations. The assay measured the relative inhibition of excess Factor Xa activity in GAG containing samples compared to a control group containing no GAG (Bramono et al., 2012).

\section{Quantikine ELISA assay}

FGF2 $(2.5 \mathrm{ng} / \mathrm{ml})$ was incubated with $2.5 \mu \mathrm{g} / \mathrm{ml}$ of HS or heparin in hMSC culture media $(1 \mathrm{ml})$ in a humidified incubator at $37{ }^{\circ} \mathrm{C}$ with $5 \% \mathrm{CO}_{2}$. The media was collected at several different time points and stored at $-80{ }^{\circ} \mathrm{C}$. FGF2 amounts present in media samples was determined by a quantitative cytokine assay (FGF2 Quantikine ELISA kit; R\&D systems) according to manufacturer's recommendations. 


\section{Differential Scanning Fluorimetry}

The thermal stability of FGF2 was assessed using the Differential Scanning Fluorimetry (DSF) technique as previously described (Uniewicz et al., 2010). Briefly, FGF2 $(10 \mu \mathrm{M})$ mixed with HS variants $(10 \mu \mathrm{M})$ was subjected to heating cycles. The denaturation curves of FGF2 with or without HS were plotted and the peak of the curve defined the melting temperature $\left(\mathrm{T}_{\mathrm{m}}\right)$ of FGF2.

\section{Cell culture}

Human MSCs were isolated in our laboratory from bone marrow mononuclear cells obtained from young healthy donors provided by Lonza as previously described (Samsonraj et al., 2015). Cells were maintained in complete Dulbecco's Modified Eagle's Medium as previously reported (Helledie et al., 2012; Ling et al., 2016).

\section{GUAVA Viacount assay}

Human MSCs $\left(3,000\right.$ cells $\left./ \mathrm{cm}^{2}\right)$ were seeded in triplicate wells and allowed to adhere overnight. Cells were treated as indicated and viable cell numbers determined using the GUAVA Flow Cytometry Viacount Program as previously described (Ling et al., 2015).

\section{Cumulative growth assay}

Human MSCs were plated at 3,000 cells $/ \mathrm{cm}^{2}$ in the presence or absence of $2.5 \mu \mathrm{g} / \mathrm{ml}$ HS8 and the number of viable cells was monitored using the GUAVA Flow Cytometry Viacount Program as previously reported (Ling et al., 2016).

\section{CFU-F assay}

Cells were seeded at low density (150 cells per 100 X 15 mm Petri dish; Nunc) and cultured in triplicate for 14 days and the medium change on day 7. Cultures were then stained 
with Crystal Violet (Sigma-Aldrich) to visualize the colonies. Colonies with more than 50 cells were counted. The CFU-F efficiency was calculated as the percentage of colonies that were formed relative to the number of cells seeded.

Flow Cytometry

Subconfluent cells were detached with $0.125 \%$ trypsin/versene solution and washed with PBS, before analyzed for stem cell surface marker expression as described previously (Helledie et al., 2012; Ling et al., 2016; Rider et al., 2008; Samsonraj et al., 2015). The number of stained cells was determined using a BD FACSArray ${ }^{\mathrm{TM}}$ Bioanalyzer and the data were analyzed using FlowJo software (Tree Star, Inc.). All antibodies and IgG isotype controls were obtained from BD Biosciences. STRO-1 antibody was a generous gift from Dr. Stan Gronthos (University of Adelaide, Australia) with the isotype control $\operatorname{IgM}(\mu)$ from Caltag Laboratories.

\section{Western blot analysis}

Cells were lysed in Laemmli buffer (Sigma Aldrich, USA) and protein lysates were denatured by heating at $95{ }^{\circ} \mathrm{C}$ for $5 \mathrm{~min}$. Lysates were then separated by SDS-PAGE, transferred to nitrocellulose membranes, and immunoblotted with the corresponding primary and secondary antibodies. The antibody against FGF2 was purchased from R\&D Systems. Antibodies against FRS2a and ERK were supplied by Cell Signaling Technology. The secondary antibodies were from Jackson ImmunoResearch Ltd. The immuno-labelled protein bands were visualized with LumiGLO Reserve chemiluminescent substrate (Kirkegaard \& Perry Laboratories). 


\section{Statistical analysis}

Each experiment was performed in triplicate, unless otherwise indicated. The data were analyzed using Graphpad Prism software (Graphpad, USA), followed by ANOVA and Bonferroni posthoc testing. Results are reported as the mean \pm SD wherever appropriate.

\section{Results}

Selection of HBD peptides with high affinity for FGF2

Several studies have reported different heparin-binding domains within FGF2 (Figs. 1A\&B). Because previous results were not entirely congruent, we re-examined the affinity of these peptides for heparin/HS in three robust assays. First, the ability of ${ }^{3} \mathrm{H}$-heparin to bind to immobilized peptides spanning these putative heparin-binding domains was determined. The data show that only a subset of the reported peptides interact with heparin in a dosedependent manner (Fig. 1C). Second, a heparin-based ELISA indicates that peptides 1, 2 and 6 have the highest affinity for heparin (Fig. 1D). Third, using HS-based ELISA we established that peptides 1 and 2 each bind HS, while the related peptide 3 does not (Fig. 1E). We note that peptide 2 contains five basic amino acids $(3 \mathrm{~K}, 1 \mathrm{R}$ and $1 \mathrm{H})$, including a central KR motif that is also found in the other putative heparin-binding domains (Fig. 1A) but missing in peptide 3 that fails to bind heparin/HS in two of our tests (Fig. 1F). The presence of basic amino acids in peptide 2 may promote electrostatic interactions between FGF2 and sulfated residues residing in heparin and HS.

\section{HS isolation using peptide affinity chromatography and disaccharide analysis}

We next used peptides 1, 2, and 3 as bait for extracting FGF2-binding HS species from commercial porcine mucosal heparan sulfate $\left(\mathrm{HS}^{\mathrm{pm}}\right)$. The resulting affinity-purified $\mathrm{HS}$ fractions are designated respectively as $\mathrm{HS}^{\mathrm{p} 1}, \mathrm{HS}^{\mathrm{p} 2}$ and $\mathrm{HS}^{\mathrm{p} 3}$ depending on the HBD peptides 
used (Fig. 2A). Affinity chromatography with each peptide yielded varying amounts of bound HS material (Fig. 2B). As each peptide was recycled several times to complete the isolation procedure, the yield represents the average, not a one-off, affinity isolation process.

Peptide 2, which is the shortest amino acid sequence containing the heparin binding domain of FGF2, yields the highest amount of bound HS material when used as a substrate for affinity chromatography $(9.05 \%)$. Notably, this yield is comparable with those observed for other HS variants isolated by our group based on affinity to other growth factors (Murali et al., 2013; Wang et al., 2014). Therefore the HS fraction isolated based on affinity for peptide $2\left(\mathrm{HS}^{\mathrm{p} 2}\right)$ was further developed as the variant HS8, consistent with previous nomenclature for validated HS variants in our research group. The disaccharide composition of crude $\mathrm{HS}^{\mathrm{pm}}$ and HS8 was analyzed using capillary electrophoresis (Fig. 2C). This analysis confirmed that the disaccharides constituting HS8 were distinct from that of the starting material, being enriched for di- ( $\Delta \mathrm{UA}-\mathrm{GlcNS}, 6 \mathrm{~S})$ and tri-sulfated $(\Delta \mathrm{UA}, 2 \mathrm{~S}-\mathrm{GlcNS}, 6 \mathrm{~S})$ motifs.

\section{Affinity of HS8 for heparin-binding growth factors}

Having isolated HS8 based on its affinity for the heparin-binding domain of FGF2, we next sought to verify its ability to bind FGF2 by ELISA (Fig. 3A). Our data show that HS8 has significantly higher affinity for FGF2 $(\mathrm{p}<0.001)$ at all FGF2 doses tested compared with the raw starting material and the flow-through fraction that is depleted of FGF2-binding HS.

We next compared the selectivity of HS8 for FGF2 over other common heparinbinding growth factors (HBGFs) using ELISA. HS8 preferentially binds FGF2 over BMP2, FGF1, FGF7, VEGF 165 and PDGF-BB (Fig. 3B). Using a combination of Western blot analysis and ELISA, we then showed that precomplexing FGF2 with heparin or HS8 $(>50$ 
$\mu \mathrm{g} / \mathrm{ml})$ blocked its ability to bind to heparin-coated beads, whilst both the raw HS starting material and the unbound flow through HS had only marginal effects (Fig. 3C\&D).

\section{Effect of HS8 on FGF2 stability}

Having shown the avidity of heparin/HS9 for FGF2, we next sought to determine the functional consequence of this interaction. Because FGF2 is unstable at physiological temperatures, and heparin is known to stabilize and protect FGF2 from degradation (Caldwell et al., 2004; Prestrelski et al., 1992; Vemuri et al., 1994), we exposed precomplexes of FGF2 and GAG to both static and ramping temperatures (Fig. 4A\&B). When exposed to $37^{\circ} \mathrm{C}$ for up to $72 \mathrm{~h}, \mathrm{FGF} 2$ rapidly degrades over the first $24 \mathrm{~h}$ with only $\sim 13 \%$ remaining and continues to degrade to a level barely detectable by $72 \mathrm{~h}$. When combined with HS, a significant increase in the amount of FGF2 was detected at all time points, irrespective of the HS variant used. Consistent with its increased affinity for FGF2, HS8 stabilized FGF2 more than the other HS variants tested with $\sim 30 \%$ still remaining after $72 \mathrm{~h}$. When ramping temperatures up to $80^{\circ} \mathrm{C}$ were applied, the melting temperature $\left(\mathrm{T}_{\mathrm{m}}\right)$ for $\mathrm{FGF} 2$ was determined to be $57.5{ }^{\circ} \mathrm{C}$ (Fig. 4B). However, precomplexing with either HS8 or $\mathrm{HS}^{\mathrm{pm}}$ increased the $\mathrm{T}_{\mathrm{m}}$ by $\sim 6{ }^{\circ} \mathrm{C}$.

\section{Anticoagulant effect of HS8}

Because $\mathrm{HS}^{\mathrm{pm}}$ is isolated during the manufacturing of the anticoagulant heparin (Griffin et al., 1995), we next evaluated the anticoagulation properties of $\mathrm{HS}^{\mathrm{pm}}$ and assessed whether affinity isolation of the FGF2-binding variant HS8 had any effect on this property (Fig. 4C). As expected, heparin significantly inactivated Factor Xa at all doses tested $(\mathrm{p}<0.001)$, whereas $\mathrm{HS}^{\mathrm{pm}}$ and its isolates, HS8 and $\mathrm{HS}^{\mathrm{ft}}$ had little ability to bind and activate antithrombin III and thereby inhibit Factor Xa. 
Effect of HS8 on FGF2 signaling

In MSCs, FGF2 exerts its mitogenic effect by binding and activating FGFR1 (Dombrowski et al., 2013; Dombrowski et al., 2009) and HS acts as an essential co-receptor for this interaction (Chellaiah et al., 1999; Dombrowski et al., 2009; Pellegrini, 2001). Whilst, FGF2 promoted hMSC growth (45\% increase), application of HS8 alone also significantly enhanced cell growth (27\% increase) (Figs. 5A\&B). Using an FGFR1-neutralizing antibody developed in our laboratory (IMB-R1) (Ling et al., 2015) and the commercial FGFR kinase inhibitor SU5402, we show that these proliferative effects were inhibited by FGFR1 inactivation (Figs. 5A\&B). Collectively, these results suggest that the mitogenic effects of HS8 are exerted through the FGFR1 pathway. As expected, IMB-R1 and SU5402 blocked FGF2-stimulated hMSC growth.

We next determined the effect of HS8 on the phosphorylation of fibroblast growth factor receptor substrate 2a (FRS2a), a key component upstream of the extracellular signalregulated kinase (ERK) pathway that regulates hMSC proliferation (Dombrowski et al., 2013; Dunican et al., 2001). Western blot analysis showed that FGF2-stimulates the phosphorylation of FRS2a and ERK that is further enhanced by HS8 (Fig. 5C).

HS8 supplementation increased the yield of hMSCs without compromising their properties

Beyond the short-term effect of HS8 on hMSC growth, we assessed whether HS8 has long-term effects on stem cell maintenance and expansion. Primary hMSCs, isolated from three donors, grew faster in the presence of HS8 over a period of 7 passages compared to control (Fig. 6A). Furthermore, HS8 supplementation also gave rise to greater numbers of colony-forming units (Fig. 6B), indicating that HS8 increases the proliferative expansion of individual clonogenic cells within the hMSC population. Importantly, HS8-expanded cells maintained their levels of key hMSC markers (Fig. 6C) compared to control, demonstrating 
that the stemness of hMSCs is maintained by HS8. Taken together, our study shows that HS8 is a FGF2-binding GAG with mitogenic bioactivity that is capable of supporting stem cell expansion.

\section{Discussion}

In this study we sought to exploit the heparin-binding domain of FGF2 to affinity isolate an HS glycosaminoglycan (HS8) for use as an adjuvant in the scale-up of hMSCs. We reasoned that HS8 would bind and potentiate the mitogenic activity of FGF2 produced by the cells and present in the serum-based culture medium. This work builds on previous success at enhancing the growth of MSCs using an HS variant (HS2) isolated from embryonic tissues (Helledie et al., 2012). Importantly, by using affinity to FGF2 to isolate HS8 from commercial sources of porcine mucosal HS $\left(\mathrm{HS}^{\mathrm{pm}}\right)$, there is now a clear strategy for the large-scale manufacturing of heparan sulfate populations with enhanced bioactivity.

Previously, native proteins have been used as substrates for affinity chromatography to isolate heparin variants with enhanced binding to growth factors or proteins, such as FGF1 (Barzu et al., 1989), FGF2 (Brickman et al., 1995) and fibronectin (Falcone and Salisbury, 1988). However, full-length protein is particularly costly and unstable. Also, columns packed with these substrates cannot be recycled. We have previously shown that synthetic HBD peptides are capable of isolating particular HS species that can promote the activity of BMP2 (Murali et al., 2013) and VEGF 165 (Wang et al., 2014).

Having isolated the FGF2-binding variant HS8, we next determined its disaccharide composition, which together with chain length and sulfation pattern, is characteristic of its ability to bind particular growth factors (Murali et al., 2011; Murali et al., 2013; Nurcombe et al., 2007; Wang et al., 2014). This is important because the disaccharide composition of HS chains governs their affinity for proteins (Lindahl et al., 1980; Maccarana et al., 1993; Pye et 
al., 1998). We show that HS8 is enriched for tri-sulfated disaccharides ( $\triangle \mathrm{UA}, 2 \mathrm{~S}-\mathrm{GlcNS}, 6 \mathrm{~S})$ and reduced for mono- and un-sulfated disaccharide. There is also an increase in di-sulfated disaccharides, particularly $\triangle \mathrm{UA}-\mathrm{GlcNS}, 6 \mathrm{~S}$. Our group has previously reported that both BMP2-binding HS (HS3) and VEGF-binding HS (HS7) also contain higher percentages of tri-sulfated disaccharides and $\triangle \mathrm{UA}-\mathrm{GlcNS}, 6 \mathrm{~S}$ disulfide species compared with the source $\mathrm{HS}^{\mathrm{pm}}$ material (Murali et al., 2013; Wang et al., 2014). Notably, $\Delta \mathrm{UA}, 2 \mathrm{~S}-\mathrm{GlcNS}, 6 \mathrm{~S}$ and $\Delta \mathrm{UA}-\mathrm{GlcNS}, 6 \mathrm{~S}$ are also key disaccharide units that are important for heparin interactions with growth factors, such as FGF2 (Ampofo et al., 1991; Jandik et al., 1994; Karamanos et al., 1996; Ruiz-Calero et al., 1998). FGF2 binding to HS is known to require both $\mathrm{N}$ - and $2 \mathrm{O}$ sulfation, with $6 O$-sulfate being necessary for the formation of an optimal FGF2:HS:FGFR1 signaling complex and subsequent phosphorylation of downstream Erk2 kinases (Lundin et al., 2000). Thus the relative level and position of sulfate groups are important for the formation of active FGF2-HS-FGFR1 ternary complexes that in turn control the mitogenic activity of FGF2 (Faham et al., 1996; Lundin et al., 2000; Maccarana et al., 1993; Pye et al., 1998).

Of the various affinity purified HSs we have produced, HS3 has the highest proportion of $\triangle \mathrm{UA}, 2 \mathrm{~S}-\mathrm{GlcNS}, 6 \mathrm{~S}(15 \%)$ and HS7 the lowest $(11 \%)$ whilst HS8 has an intermediate amount (13\%). Comparing $\triangle \mathrm{UA}-\mathrm{GlcNS}, 6 \mathrm{~S}$ groups, HS7 has the highest $(15 \%)$ and HS3 the lowest (11\%) with HS8 in between (13\%). Differences in these important disaccharides presumably contribute to the particular growth factor binding profiles of these HS variants.

The kinetics of growth factors within tissues is important for maintaining their biological effect (Beenken and Mohammadi, 2009). Stability is a key determinant of growth factor activity, particularly as it relates to the effect of FGF2 on stem cell self-renewal, differentiation, and reprogramming (Chen et al., 2012). Notably, the average half-life of 
FGF2 in the body has been reported to be as low as 7.6 hours (Lundin et al., 2000). To address this shortcoming, heparin is frequently used as a media additive because it is known to protect FGF2 from thermal degradation (Beenken and Mohammadi, 2009; Bush et al., 2001; Uniewicz et al., 2010) yet its cautious use as a culture adjuvant is needed because heparin could alter the biological properties of stem cells (Ling et al., 2016). In the present study, HS8 increased the thermal stability of FGF2 by $6^{\circ} \mathrm{C}$ and increased FGF2-mediated hMSC proliferation through FGFR1. Complexes of FGF2 and HS8 also prolonged FGFR signaling through the ERK pathway. Importantly, the number of clonogenic hMSCs was also significantly higher with HS8 supplementation, suggesting that HS8 targeted the expansion of more naïve cells in the hMSC pool.

Recently we have shown that FGFR1 signalling is essential for hMSC self-renewal, primarily through the inactivation of cyclin-dependent kinase inhibitors $\mathrm{p} 21^{\mathrm{Waf} 1}$ and $\mathrm{p} 27^{\mathrm{Kip} 1}$ (Dombrowski et al., 2013). Developing HS variants that target FGF2 (HS8) highlight the potential that selected glycosaminoglycans have as co-factors capable of enhancing FGF:FGFR signaling. The ability to enhance these interactions is proving a useful strategy for mediating hMSC biology without the needs for exogenous applications of recombinant growth factors.

In this study, we have successfully purified an FGF2-binding HS variant (HS8) using peptide-affinity chromatography against the heparin-binding domain of FGF2. HS8 was isolated from a commercially available, porcine intestinal mucosal HS preparation with an approach that is simple, reproducible and readily scalable. We show that HS8 has enhanced affinity for FGF2, and promotes FGF2 signaling through a disaccharide composition enriched for trisulfated and certain disulfated disaccharide moieties. Most importantly, our work suggests that this affinity-selection approach is effective in generating an HS variant that can 
increase the proliferation of clonogenic hMSCs through the FGFR axis without compromising their stemness.

\title{
Acknowledgment
}

The work was funded by Agency for Science, Technology and Research (A*STAR) of Singapore and the National Medical Research Council of Singapore (Grant NMRC BNB003b). We also appreciate the generous philanthropic support of William and Karen Eby, as well as the charitable foundation in their names (to $\mathrm{AJvW}$ ).

\begin{abstract}
Abbreviations
Ahx, aminohexanoic acid; BMMNCs, bone marrow mononuclear cells; CE, capillary electrophoresis; cpm, count per minute; DSF, Differential Scanning Fluorimetry; FGF, fibroblast growth factor; HBD, heparin-binding domain; hMSCs, human bone marrowderived mesenchymal stem cells; HS, heparan sulfate; HSPGs, heparan sulfate proteoglycans; $\mathrm{HS}^{\mathrm{pm}}$, porcine mucosal heparan sulfate; PDGF, platelet-derived growth factor.
\end{abstract}

\section{References}

Ampofo SA, Wang HM, Linhardt RJ. 1991. Disaccharide compositional analysis of heparin and heparan sulfate using capillary zone electrophoresis. Analytical biochemistry 199(2):249255.

Ashikari-Hada S, Habuchi H, Kariya Y, Itoh N, Reddi AH, Kimata K. 2004. Characterization of growth factor-binding structures in heparin/heparan sulfate using an octasaccharide library. The Journal of biological chemistry 279(13):12346-12354.

Auletta JJ, Zale EA, Welter JF, Solchaga LA. 2011. Fibroblast Growth Factor-2 Enhances Expansion of Human Bone Marrow-Derived Mesenchymal Stromal Cells without Diminishing Their Immunosuppressive Potential. Stem cells international 2011:235176.

Baird A, Schubert D, Ling N, Guillemin R. 1988. Receptor- and heparin-binding domains of basic fibroblast growth factor. Proceedings of the National Academy of Sciences of the United States of America 85(7):2324-2328.

Barzu T, Lormeau JC, Petitou M, Michelson S, Choay J. 1989. Heparin-derived oligosaccharides: affinity for acidic fibroblast growth factor and effect on its growth- 
promoting activity for human endothelial cells. Journal of cellular physiology 140(3):538548.

Beenken A, Mohammadi M. 2009. The FGF family: biology, pathophysiology and therapy. Nature reviews Drug discovery 8(3):235-253.

Bramono DS, Murali S, Rai B, Ling L, Poh WT, Lim ZX, Stein GS, Nurcombe V, van Wijnen AJ, Cool SM. 2012. Bone marrow-derived heparan sulfate potentiates the osteogenic activity of bone morphogenetic protein-2 (BMP-2). Bone 50(4):954-964.

Brickman YG, Ford MD, Small DH, Bartlett PF, Nurcombe V. 1995. Heparan sulfates mediate the binding of basic fibroblast growth factor to a specific receptor on neural precursor cells. The Journal of biological chemistry 270(42):24941-24948.

Bueno EM, Glowacki J. 2009. Cell-free and cell-based approaches for bone regeneration. Nature reviews Rheumatology 5(12):685-697.

Bush MA, Samara E, Whitehouse MJ, Yoshizawa C, Novicki DL, Pike M, Laham RJ, Simons M, Chronos NA. 2001. Pharmacokinetics and pharmacodynamics of recombinant FGF-2 in a phase I trial in coronary artery disease. Journal of clinical pharmacology 41(4):378-385.

Caldwell MA, Garcion E, terBorg MG, He X, Svendsen CN. 2004. Heparin stabilizes FGF-2 and modulates striatal precursor cell behavior in response to EGF. Experimental neurology 188(2):408-420.

Caplan AI. 2009. Why are MSCs therapeutic? New data: new insight. The Journal of pathology 217(2):318-324.

Caplan AI, Correa D. 2011. The MSC: an injury drugstore. Cell stem cell 9(1):11-15. Cardin AD, Weintraub HJ. 1989. Molecular modeling of protein-glycosaminoglycan interactions. Arteriosclerosis 9(1):21-32.

Chatterjea A, Meijer G, van Blitterswijk C, de Boer J. 2010. Clinical application of human mesenchymal stromal cells for bone tissue engineering. Stem cells international 2010:215625.

Chellaiah A, Yuan W, Chellaiah M, Ornitz DM. 1999. Mapping ligand binding domains in chimeric fibroblast growth factor receptor molecules. Multiple regions determine ligand binding specificity. The Journal of biological chemistry 274(49):34785-34794.

Chen G, Gulbranson DR, Yu P, Hou Z, Thomson JA. 2012. Thermal stability of fibroblast growth factor protein is a determinant factor in regulating self-renewal, differentiation, and reprogramming in human pluripotent stem cells. Stem Cells 30(4):623-630.

Chen L, Tredget EE, Wu PY, Wu Y. 2008. Paracrine factors of mesenchymal stem cells recruit macrophages and endothelial lineage cells and enhance wound healing. PLoS One 3(4):e1886.

Dombrowski C, Helledie T, Ling L, Grunert M, Canning CA, Jones CM, Hui JH, Nurcombe V, van Wijnen AJ, Cool SM. 2013. FGFR1 signaling stimulates proliferation of human mesenchymal stem cells by inhibiting the cyclin-dependent kinase inhibitors p21(Waf1) and p27(Kip1). Stem Cells 31(12):2724-2736.

Dombrowski C, Song SJ, Chuan P, Lim X, Susanto E, Sawyer AA, Woodruff MA, Hutmacher DW, Nurcombe V, Cool SM. 2009. Heparan sulfate mediates the proliferation and differentiation of rat mesenchymal stem cells. Stem cells and development 18(4):661670.

Dunican DJ, Williams EJ, Howell FV, Doherty P. 2001. Selective inhibition of fibroblast growth factor (FGF)-stimulated mitogenesis by a FGF receptor-1-derived phosphopeptide. Cell growth \& differentiation : the molecular biology journal of the American Association for Cancer Research 12(5):255-264.

Faham S, Hileman RE, Fromm JR, Linhardt RJ, Rees DC. 1996. Heparin structure and interactions with basic fibroblast growth factor. Science 271(5252):1116-1120. 
Falcone DJ, Salisbury BG. 1988. Fibronectin stimulates macrophage uptake of low density lipoprotein-heparin-collagen complexes. Arteriosclerosis 8(3):263-273.

Frescaline G, Bouderlique T, Huynh MB, Papy-Garcia D, Courty J, Albanese P. 2012.

Glycosaminoglycans mimetics potentiate the clonogenicity, proliferation, migration and

differentiation properties of rat mesenchymal stem cells. Stem cell research 8(2):180-192.

Gandhi NS, Mancera RL. 2008. The structure of glycosaminoglycans and their interactions with proteins. Chemical biology \& drug design 72(6):455-482.

Gharibi B, Hughes FJ. 2012. Effects of medium supplements on proliferation, differentiation potential, and in vitro expansion of mesenchymal stem cells. Stem cells translational medicine 1(11):771-782.

Griffin CC, Linhardt RJ, Van Gorp CL, Toida T, Hileman RE, Schubert RL, 2nd, Brown SE. 1995. Isolation and characterization of heparan sulfate from crude porcine intestinal mucosal peptidoglycan heparin. Carbohydrate research 276(1):183-197.

Gronthos S, Zannettino AC, Graves SE, Ohta S, Hay SJ, Simmons PJ. 1999. Differential cell surface expression of the STRO-1 and alkaline phosphatase antigens on discrete developmental stages in primary cultures of human bone cells. Journal of bone and mineral research : the official journal of the American Society for Bone and Mineral Research 14(1):47-56.

Hagmann S, Moradi B, Frank S, Dreher T, Kammerer PW, Richter W, Gotterbarm T. 2013. FGF-2 addition during expansion of human bone marrow-derived stromal cells alters MSC surface marker distribution and chondrogenic differentiation potential. Cell proliferation 46(4):396-407.

Helledie T, Dombrowski C, Rai B, Lim ZX, Hin IL, Rider DA, Stein GS, Hong W, van Wijnen AJ, Hui JH, Nurcombe V, Cool SM. 2012. Heparan sulfate enhances the self-renewal and therapeutic potential of mesenchymal stem cells from human adult bone marrow. Stem cells and development 21(11):1897-1910.

Jandik KA, Gu K, Linhardt RJ. 1994. Action pattern of polysaccharide lyases on glycosaminoglycans. Glycobiology 4(3):289-296.

Karamanos NK, Vanky P, Tzanakakis GN, Hjerpe A. 1996. High performance capillary electrophoresis method to characterize heparin and heparan sulfate disaccharides.

Electrophoresis 17(2):391-395.

Kinsella L, Chen HL, Smith JA, Rudland PS, Fernig DG. 1998. Interactions of putative heparin-binding domains of basic fibroblast growth factor and its receptor, FGFR-1, with heparin using synthetic peptides. Glycoconjugate journal 15(4):419-422.

Le Blanc K, Frassoni F, Ball L, Locatelli F, Roelofs H, Lewis I, Lanino E, Sundberg B, Bernardo ME, Remberger M, Dini G, Egeler RM, Bacigalupo A, Fibbe W, Ringden O. 2008. Mesenchymal stem cells for treatment of steroid-resistant, severe, acute graft-versus-host disease: a phase II study. Lancet 371(9624):1579-1586.

Lee JY, Choo JE, Choi YS, Lee KY, Min DS, Pi SH, Seol YJ, Lee SJ, Jo IH, Chung CP, Park YJ. 2007. Characterization of the surface immobilized synthetic heparin binding domain derived from human fibroblast growth factor-2 and its effect on osteoblast differentiation. Journal of biomedical materials research Part A 83(4):970-979.

Lindahl U, Backstrom G, Thunberg L, Leder IG. 1980. Evidence for a 3-O-sulfated Dglucosamine residue in the antithrombin-binding sequence of heparin. Proceedings of the National Academy of Sciences of the United States of America 77(11):6551-6555.

Ling L, Camilleri ET, Helledie T, Samsonraj RM, Titmarsh DM, Chua RJ, Dreesen O, Dombrowski C, Rider DA, Galindo M, Lee I, Hong W, Hui JH, Nurcombe V, van Wijnen AJ, Cool SM. 2016. Effect of heparin on the biological properties and molecular signature of human mesenchymal stem cells. Gene 576(1 Pt 2):292-303. 
Ling L, Murali S, Dombrowski C, Haupt LM, Stein GS, van Wijnen AJ, Nurcombe V, Cool SM. 2006. Sulfated glycosaminoglycans mediate the effects of FGF2 on the osteogenic potential of rat calvarial osteoprogenitor cells. Journal of cellular physiology 209(3):811-825. Ling L, Tan SK, Goh TH, Cheung E, Nurcombe V, van Wijnen AJ, Cool SM. 2015. Targeting the heparin-binding domain of fibroblast growth factor receptor 1 as a potential cancer therapy. Molecular cancer 14:136.

Lundin L, Larsson H, Kreuger J, Kanda S, Lindahl U, Salmivirta M, Claesson-Welsh L. 2000. Selectively desulfated heparin inhibits fibroblast growth factor-induced mitogenicity and angiogenesis. The Journal of biological chemistry 275(32):24653-24660.

Maccarana M, Casu B, Lindahl U. 1993. Minimal sequence in heparin/heparan sulfate required for binding of basic fibroblast growth factor. The Journal of biological chemistry 268(32):23898-23905.

Martin I, Muraglia A, Campanile G, Cancedda R, Quarto R. 1997. Fibroblast growth factor-2 supports ex vivo expansion and maintenance of osteogenic precursors from human bone marrow. Endocrinology 138(10):4456-4462.

Maxson S, Lopez EA, Yoo D, Danilkovitch-Miagkova A, Leroux MA. 2012. Concise review: role of mesenchymal stem cells in wound repair. Stem cells translational medicine 1(2):142149.

Meuleman N, Tondreau T, Ahmad I, Kwan J, Crokaert F, Delforge A, Dorval C, Martiat P, Lewalle P, Lagneaux L, Bron D. 2009. Infusion of mesenchymal stromal cells can aid hematopoietic recovery following allogeneic hematopoietic stem cell myeloablative transplant: a pilot study. Stem cells and development 18(9):1247-1252.

Morigi M, Imberti B, Zoja C, Corna D, Tomasoni S, Abbate M, Rottoli D, Angioletti S, Benigni A, Perico N, Alison M, Remuzzi G. 2004. Mesenchymal stem cells are renotropic, helping to repair the kidney and improve function in acute renal failure. Journal of the American Society of Nephrology : JASN 15(7):1794-1804.

Murali S, Leong DF, Lee JJ, Cool SM, Nurcombe V. 2011. Comparative assessment of the effects of gender-specific heparan sulfates on mesenchymal stem cells. The Journal of biological chemistry 286(20):17755-17765.

Murali S, Rai B, Dombrowski C, Lee JL, Lim ZX, Bramono DS, Ling L, Bell T, Hinkley S, Nathan SS, Hui JH, Wong HK, Nurcombe V, Cool SM. 2013. Affinity-selected heparan sulfate for bone repair. Biomaterials 34(22):5594-5605.

Ng F, Boucher S, Koh S, Sastry KS, Chase L, Lakshmipathy U, Choong C, Yang Z, Vemuri MC, Rao MS, Tanavde V. 2008. PDGF, TGF-beta, and FGF signaling is important for differentiation and growth of mesenchymal stem cells (MSCs): transcriptional profiling can identify markers and signaling pathways important in differentiation of MSCs into adipogenic, chondrogenic, and osteogenic lineages. Blood 112(2):295-307.

Nugent MA, Edelman ER. 1992. Kinetics of basic fibroblast growth factor binding to its receptor and heparan sulfate proteoglycan: a mechanism for cooperactivity. Biochemistry 31(37):8876-8883.

Nurcombe V, Goh FJ, Haupt LM, Murali S, Cool SM. 2007. Temporal and functional changes in glycosaminoglycan expression during osteogenesis. Journal of molecular histology 38(5):469-481.

Nurcombe V, Smart CE, Chipperfield H, Cool SM, Boilly B, Hondermarck H. 2000. The proliferative and migratory activities of breast cancer cells can be differentially regulated by heparan sulfates. The Journal of biological chemistry 275(39):30009-30018.

Ori A, Free P, Courty J, Wilkinson MC, Fernig DG. 2009. Identification of heparin-binding sites in proteins by selective labeling. Molecular \& cellular proteomics : MCP 8(10):22562265. 
Ori A, Wilkinson MC, Fernig DG. 2008. The heparanome and regulation of cell function: structures, functions and challenges. Frontiers in bioscience : a journal and virtual library 13:4309-4338.

Pellegrini L. 2001. Role of heparan sulfate in fibroblast growth factor signalling: a structural view. Current opinion in structural biology 11(5):629-634.

Prestrelski SJ, Fox GM, Arakawa T. 1992. Binding of heparin to basic fibroblast growth factor induces a conformational change. Archives of biochemistry and biophysics 293(2):314-319.

Pye DA, Vives RR, Turnbull JE, Hyde P, Gallagher JT. 1998. Heparan sulfate oligosaccharides require 6-O-sulfation for promotion of basic fibroblast growth factor mitogenic activity. The Journal of biological chemistry 273(36):22936-22942.

Ren G, Su J, Zhang L, Zhao X, Ling W, L'Huillie A, Zhang J, Lu Y, Roberts AI, Ji W, Zhang H, Rabson AB, Shi Y. 2009. Species variation in the mechanisms of mesenchymal stem cellmediated immunosuppression. Stem Cells 27(8):1954-1962.

Rider DA, Dombrowski C, Sawyer AA, Ng GH, Leong D, Hutmacher DW, Nurcombe V, Cool SM. 2008. Autocrine fibroblast growth factor 2 increases the multipotentiality of human adipose-derived mesenchymal stem cells. Stem Cells 26(6):1598-1608.

Ruiz-Calero V, Puignou L, Galceran MT. 1998. Use of reversed polarity and a pressure gradient in the analysis of disaccharide composition of heparin by capillary electrophoresis. Journal of chromatography A 828(1-2):497-508.

Samsonraj RM, Rai B, Sathiyanathan P, Puan KJ, Rotzschke O, Hui JH, Raghunath M, Stanton LW, Nurcombe V, Cool SM. 2015. Establishing criteria for human mesenchymal stem cell potency. Stem Cells.

Shabbir A, Zisa D, Suzuki G, Lee T. 2009. Heart failure therapy mediated by the trophic activities of bone marrow mesenchymal stem cells: a noninvasive therapeutic regimen. American journal of physiology Heart and circulatory physiology 296(6):H1888-1897. Shi Y, Hu G, Su J, Li W, Chen Q, Shou P, Xu C, Chen X, Huang Y, Zhu Z, Huang X, Han X, Xie N, Ren G. 2010. Mesenchymal stem cells: a new strategy for immunosuppression and tissue repair. Cell research 20(5):510-518.

Shin L, Peterson DA. 2013. Human mesenchymal stem cell grafts enhance normal and impaired wound healing by recruiting existing endogenous tissue stem/progenitor cells. Stem cells translational medicine 2(1):33-42.

Sotiropoulou PA, Perez SA, Salagianni M, Baxevanis CN, Papamichail M. 2006.

Characterization of the optimal culture conditions for clinical scale production of human mesenchymal stem cells. Stem Cells 24(2):462-471.

Syed BA, Evans JB. 2013. Stem cell therapy market. Nature reviews Drug discovery 12(3):185-186.

Toubai T, Paczesny S, Shono Y, Tanaka J, Lowler KP, Malter CT, Kasai M, Imamura M. 2009. Mesenchymal stem cells for treatment and prevention of graft-versus-host disease after allogeneic hematopoietic cell transplantation. Current stem cell research \& therapy 4(4):252259.

Tsutsumi S, Shimazu A, Miyazaki K, Pan H, Koike C, Yoshida E, Takagishi K, Kato Y. 2001. Retention of multilineage differentiation potential of mesenchymal cells during proliferation in response to FGF. Biochem Biophys Res Commun 288(2):413-419. Undale AH, Westendorf JJ, Yaszemski MJ, Khosla S. 2009. Mesenchymal stem cells for bone repair and metabolic bone diseases. Mayo Clinic proceedings 84(10):893-902. Uniewicz KA, Ori A, Xu R, Ahmed Y, Wilkinson MC, Fernig DG, Yates EA. 2010. Differential scanning fluorimetry measurement of protein stability changes upon binding to glycosaminoglycans: a screening test for binding specificity. Anal Chem 82(9):3796-3802. 
Vemuri S, Beylin I, Sluzky V, Stratton P, Eberlein G, Wang YJ. 1994. The stability of bFGF against thermal denaturation. The Journal of pharmacy and pharmacology 46(6):481-486.

Walsh S, Jefferiss C, Stewart K, Jordan GR, Screen J, Beresford JN. 2000. Expression of the developmental markers STRO-1 and alkaline phosphatase in cultures of human marrow stromal cells: regulation by fibroblast growth factor (FGF)-2 and relationship to the expression of FGF receptors 1-4. Bone 27(2):185-195.

Wang C, Poon S, Murali S, Koo CY, Bell TJ, Hinkley SF, Yeong H, Bhakoo K, Nurcombe V, Cool SM. 2014. Engineering a vascular endothelial growth factor 165-binding heparan sulfate for vascular therapy. Biomaterials 35(25):6776-6786.

Wu Y, Huang S, Enhe J, Ma K, Yang S, Sun T, Fu X. 2014. Bone marrow-derived mesenchymal stem cell attenuates skin fibrosis development in mice. International wound journal 11(6):701-710.

Figure legends

Figure 1: Affinity of heparan sugars to reported HBDs of FGF2. $A$ and $B$, Illustration of 10 reported sequences of HBDs in FGF2. $C$, The affinity of synthetic HBD peptides to tritium-labelled heparin $\left({ }^{3} \mathrm{H}\right.$-heparin). $D$ and $E$, The affinity of synthetic HBD peptides to heparin or $\mathrm{HS}^{\mathrm{pm}}$ as determined by ELISA. $F$, Summary of heparin/HS affinity to HBD peptides. Positive affinity is indicated with “+”, while low or no affinity is indicated with "-”.

Figure 2: Purification and characterisation of FGF2-binding HS (HS8). $A$, Affinity chromatography of HS fractions. Biotinylated FGF2-HBD peptides 1, 2 and 3 were used to isolate HS variants $\mathrm{HS}^{\mathrm{p} 1}, \mathrm{HS}^{\mathrm{p} 2}$ and $\mathrm{HS}^{\mathrm{p} 3}$, respectively. $B$, The yield of the three HS variants. $C$, Disaccharide profile of $\mathrm{HS}^{\mathrm{p} 2}$ (HS8) compared with the starting HS material $\mathrm{HS}^{\mathrm{pm}}$.

Figure 3: Affinity of HS8 to FGF2. $A$, The differential affinity of HS8, starting HS material $\left(\mathrm{HS}^{\mathrm{pm}}\right)$ and flow through HS (HS $\left.{ }^{\mathrm{ft}}\right)$ to FGF2 was revealed by GAG-Protein ELISA. $B$, The affinity of HS8 to other heparin-binding growth factors was examined using GAG-Protein 
ELISA. $C$ and $D$, The ability of HS8 $(5,50$ or $100 \mu \mathrm{g} / \mathrm{ml})$ to compete with heparin for FGF2 $(10 \mathrm{ng} / \mathrm{ml})$ was assessed using heparin-agarose bead competition assay. $\mathrm{HS}^{\mathrm{pm}}$ and $\mathrm{HS}^{\mathrm{ft}}$ at the same concentration as HS8 were also included in the comparison. FGF2 pulled down by heparin-agarose beads was assessed by Western blotting (C) (data from a single sample), or by ELISA (D).

Figure 4: Effect of HS8 on FGF2 stability and Factor Xa activity. $A$, Temporal stability of FGF2 in the presence of HS variants as determined by Quantikine ELISA. $B$, Thermal stability of FGF2 in the presence of HS variants as determined by fluorimetry. $C$, Effect of HS variants on Factor Xa activity (relative to no GAG condition).

Figure 5: Effect of HS8 on FGF2-FGFR1 activity. $A-B$, Human MSCs seeded at 3,000 cells $/ \mathrm{cm}^{2}$ were pre-treated with the either IMB-R1 (1:1000 dilution) or SU5402 (10 $\left.\mu \mathrm{M}\right) 30$ min before addition of FGF2 $(2.5 \mathrm{ng} / \mathrm{ml})$ or HS8 $(2.5 \mu \mathrm{g} / \mathrm{ml})$. Medium including the corresponding reagents were refreshed every 2-3 days. After 4 days, the viable hMSCs were counted using GUAVA Viacount assay. IMB-R1 is the neutralizing antibody for FGFR1; SU5402 is the small chemical inhibitor of FGFR kinase. $C$, Human MSCs seeded at 10,000 cells $/ \mathrm{cm}^{2}$ were allowed to attach overnight before being starved by serum-deprival for $48 \mathrm{~h}$. Cells were then treated with GAGs $(2.5 \mu \mathrm{g} / \mathrm{ml})$ and/or suboptimal amounts of FGF2 (0.156 $\mathrm{ng} / \mathrm{ml}$ ) for $24 \mathrm{~h}$, before the levels of target proteins were detected by Western blot (data from a single sample).

Figure 6: Effect of HS8 on hMSC properties. A, The cumulative number of hMSCs serially passaged with or without $2.5 \mu \mathrm{g} / \mathrm{ml} \mathrm{HS8}$ were monitored using GUAVA Viacount assay (data from a single sample of each donor). $B$, Clonogenicity was assessed after serial 
passaging to $\mathrm{P} 7$ as above using a CFU-F assay. C, Assessment of cell surface antigens by flow cytometry after serial passaging to $\mathrm{P} 7$ as above (data from a single sample). 
Fig. 1

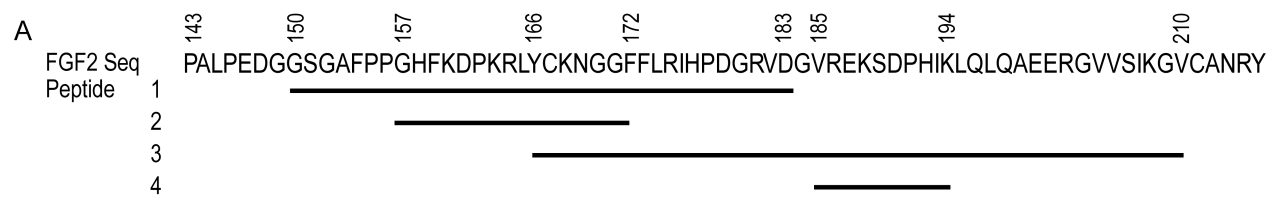
$\stackrel{\circ}{\sim}$

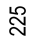
$\stackrel{\mathscr{N}}{\sim}$

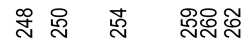

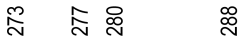
LAMKEDGRLLASKCVTDECFFFERLESNNYNTYRSRKYTSWYVALKRTGQYKLGSKTGPGQKAILFLPMSAKS

B

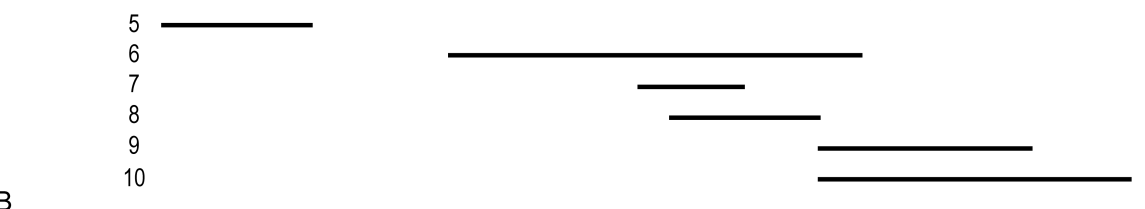

\begin{tabular}{crll}
\hline Peptide & Seq ID & \multicolumn{1}{c}{ Sequence } & \multicolumn{1}{c}{ Reference } \\
\hline 1 & $150-183$ & GSGAFPPGHFKDPKRLYCKNGGFFLRIHPDGRVD & Cardin et al, 1989 \\
2 & $157-172$ & GHFKDPKRLYCKNGGF & Gandhi et al, 2008 \\
3 & $166-210$ & YCKNGGFFLRIHPDGRVDGVREKSDPHIKLQLQAEERGVVSIKGV & Baird et al, 1998 \\
4 & $185-194$ & VREKSDPHIK & Kinsella et al, 1998 \\
5 & $216-225$ & LAMKEDGRLL & Ori et al, 2009 \\
6 & $235-262$ & FFFERLESNNYNTYRSRKYTSWYVALKR & Baird et al, 1998 \\
7 & $248-254$ & YRSRKYT & Lee et al, 2007 \\
8 & $250-259$ & SRKYTSWYVA & Kinsella et al, 1998 \\
9 & $260-273$ & LKRTGQYKLGSKTG & Kinsella et al, 1998 \\
10 & $260-280$ & LKRTGQYKLGSKTGPGQKAIL & Ashikari-Hada et al, 2004
\end{tabular}
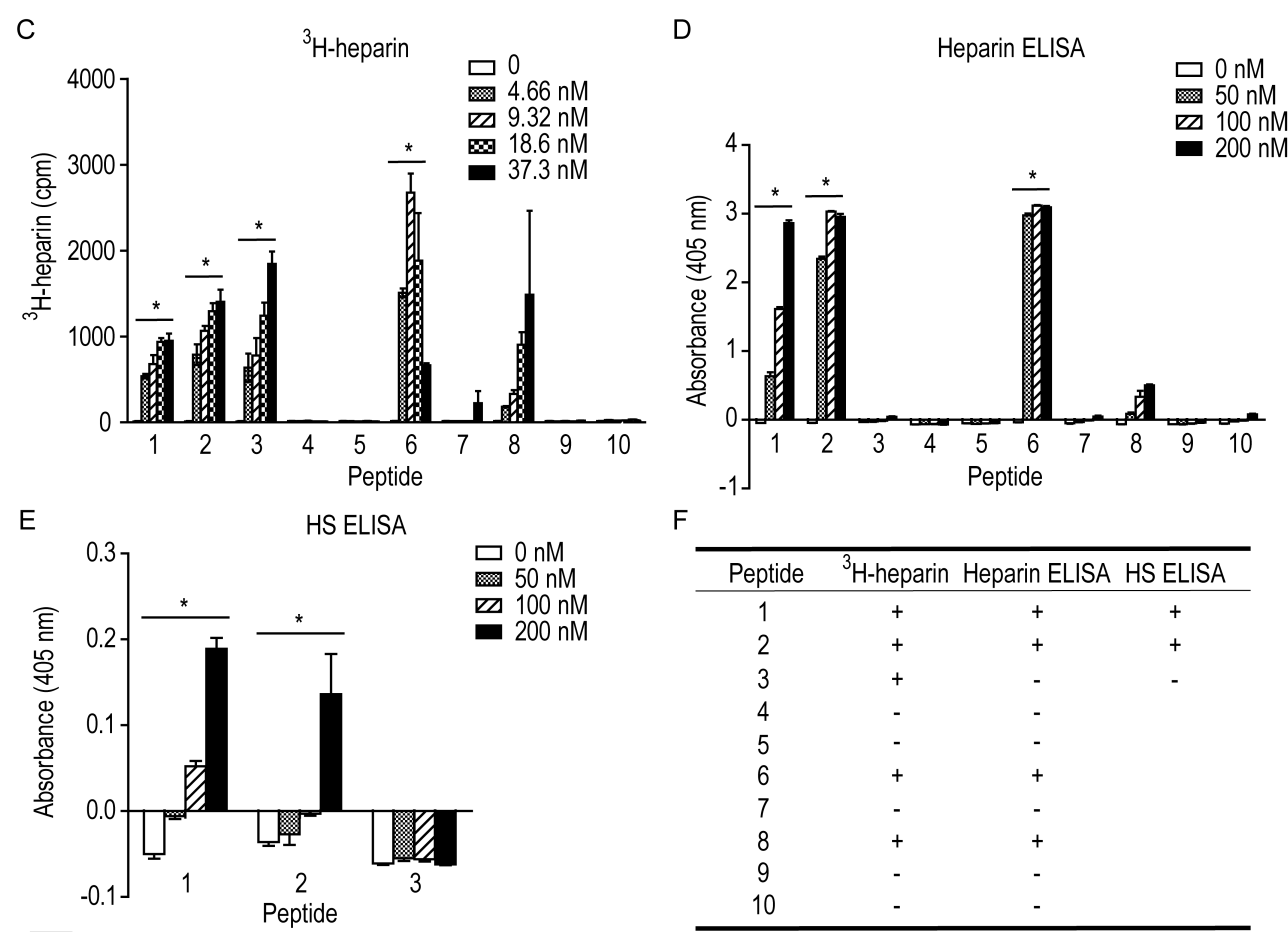

$\mathrm{F}$

\begin{tabular}{cccc}
\hline Peptide & ${ }^{3}$ H-heparin & Heparin ELISA HS ELISA \\
\hline 1 & + & + & + \\
2 & + & + & + \\
3 & + & - & - \\
4 & - & - & \\
5 & - & - & \\
6 & + & + & \\
7 & - & - & \\
8 & + & + & \\
9 & - & - & \\
10 & - & - & \\
\hline
\end{tabular}

Fig1 . 
Fig2 . 
Fig. 3

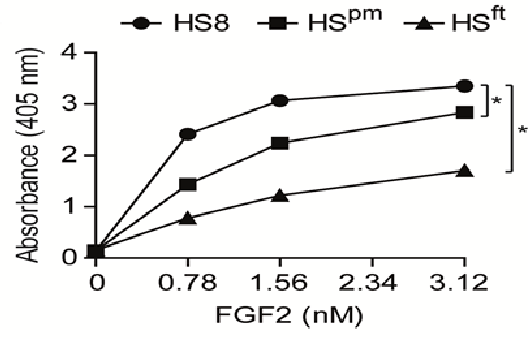

$$
\underline{\text { Heparin }} \mathrm{HS8} \mathrm{HS}^{\mathrm{pm}} \mathrm{HS}^{\mathrm{ft}}
$$

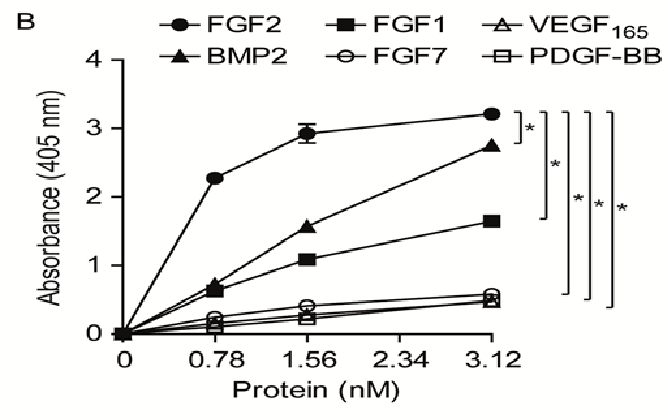

$0550100550100550100550100(\mu \mathrm{g} / \mathrm{ml})$
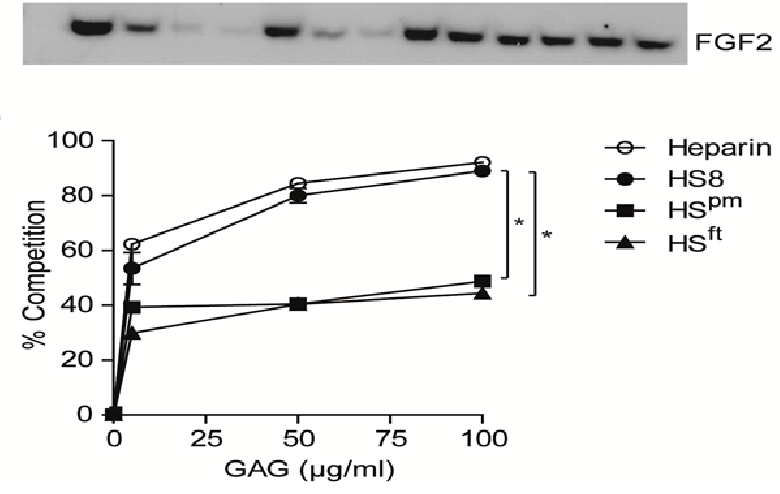

Fig3 . 
Fig. 4

A
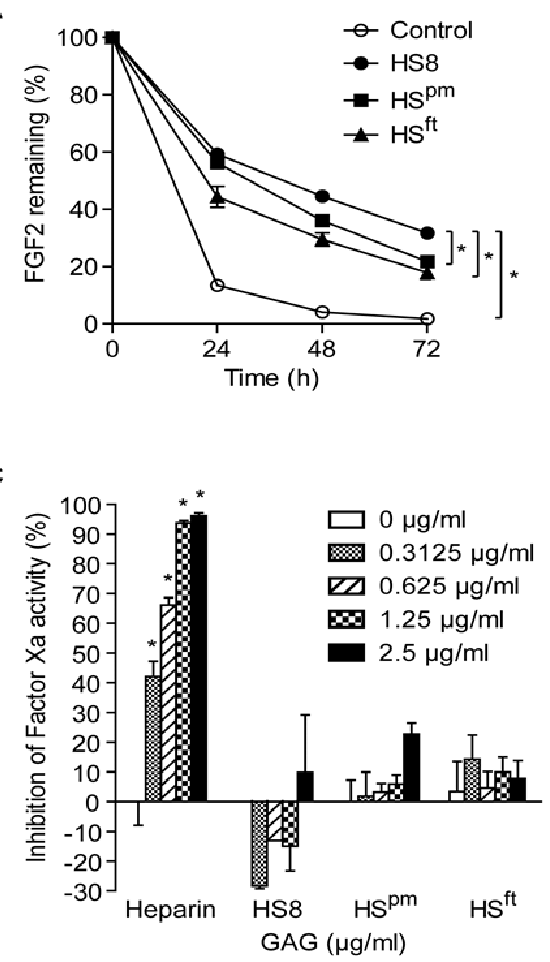

B

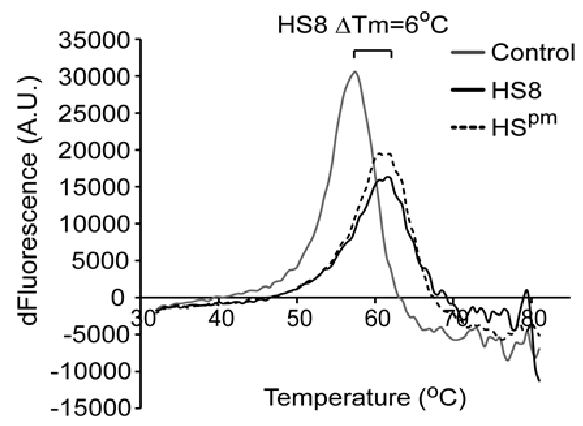

Fig4 . 
Fig5 . 
Fig6 . 


\section{University Library}

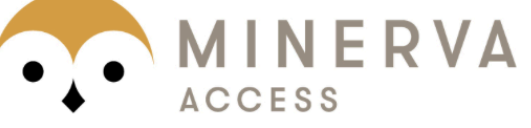

A gateway to Melbourne's research publications

Minerva Access is the Institutional Repository of The University of Melbourne

\section{Author/s:}

Wijesinghe, SJ;Ling, L;Murali, S;Qing, YH;Hinkley, SFR;Carnachan, SM;Bell, TJ;Swaminathan, K;Hui, JH;van Wijnen, AJ;Nurcombe, V;Cool, SM

Title:

Affinity Selection of FGF2-Binding Heparan Sulfates for Ex Vivo Expansion of Human Mesenchymal Stem Cells.

Date:

2017-03

Citation:

Wijesinghe, S. J., Ling, L., Murali, S., Qing, Y. H., Hinkley, S. F. R., Carnachan, S. M., Bell, T. J., Swaminathan, K., Hui, J. H., van Wijnen, A. J., Nurcombe, V. \& Cool, S. M. (2017). Affinity Selection of FGF2-Binding Heparan Sulfates for Ex Vivo Expansion of Human Mesenchymal Stem Cells.. J Cell Physiol, 232 (3), pp.566-575. https://doi.org/10.1002/jcp.25454.

Persistent Link:

http://hdl.handle.net/11343/291459 